\title{
PERBANDINGAN KEEFEKTIFAN PEMBELAJARAN COOPERATIVE LEARNING TYPE STAD DAN TYPE TPS PADA PEMBELAJARAN BANGUN RUANG SISWA SMP
}

\author{
Astri Wahyuni ${ }^{1)}$, Agus Maman Abadi ${ }^{2)}$ \\ Prodi Pendidikan Matematika PPs UNY ${ }^{1)}$, Universitas Negeri Yogyakarta ${ }^{2)}$ \\ Astriwahyuni280@gmail.com ${ }^{1)}$, agusmaman@uny.ac.id ${ }^{2)}$
}

\begin{abstract}
Abstrak
Penelitian ini bertujuan untuk mendeskripsikan keefektifan pembelajaran cooperative learning (type student team achiement division dan type think-pair-share) dan keefektifan pembelajaran cooperative learning type student team achiement division dibandingkan dengan pembelajaran cooperative lerning type think-pair-share ditinjau dari aspek ketercapaian standar kompetensi, kemampuan komunikasi matematika, dan berpikir matematis siswa SMP. Jenis penelitian ini adalah quasi experiment dengan pretest-posttest nonequivalent group design. Populasi dan sampelnya adalah siswa Kelas VIII SMP Negeri 7 Yogyakarta dan siswa Kelas VIII A dan VIII B.Untuk menguji keefektifan metode (type student team achiement division dan type think-pair-share), data dianalisis menggunakan uji one sample t-test. Untuk menguji bahwa metode type student team achiement division lebih efektif daripada metode think-pair-share, data dianalisis menggunakan MANOVA yang dilanjutkan dengan uji $t$ Benferroni. Hasil penelitian menunjukkan bahwa metode pembelajaran (type student team achiement division dan type think-pair-share) efektif dan metode type student team achiement division lebih efektif daripada metode type think-pair-share ditinjau dari aspek ketercapaian standar kompetensi, kemampuan komunikasi matematika, dan berpikir matematis siswa SMP.
\end{abstract}

Kata kunci: Pembelajaran Cooperative Learning Type STAD, Cooperative Learning Type TPS, Ketercapaian Standar Kompetensi, Kemampuan Komunikasi Matematika, Berpikir matematis

\section{COMPARISON BETWEEN THE EFFECTIVENESS OF THE STAD AND TPS COOPERATIVE LEARNING IN GEOMETRIC OF JUNIOR HIGH SCHOOL STUDENTS}

\begin{abstract}
This study aims to describe the effectiveness between the student team achievement division and think-pair-share cooperative learning and the effectiveness of the student team achievement division compared with think-pair-share cooperative learning in the mathematics competence standard attainment, mathematical communication skill, and mathematical thinking of junior high school students. This study was a quasi experimental study using the pretest-posttest nonequivalent group design. The research population comprised all Year VIII students of SMP Negeri 7 Yogyakarta. From the population, two classes, Class VIII A and Class VIII B, were selected randomly as the research sample. To test the effectiveness of the student team achievement division and think-pair-share, the one sample t-test was carried out. Then, to test the more effectiveness of the student team achievement division than the think-pair-share, the MANOVA was carried out and then continued by the $t$ Benferroni test. The results of the study show that the student team achievement division and thinkpair-share are effective and the student team achievement division is more effective than the thinkpair-share cooperative learning in the mathematics competence standard attainment, mathematical communication skill, and mathematical thinking of junior high school students.
\end{abstract}

Keywords: Cooperative learning type STAD, Coperative learning type TPS, mathematics competence standard attainment, mathematical communication skill, and mathematical thinking. 


\section{PENDAHULUAN}

Kemajuan ilmu pengetahuan dan teknologi menuntut seseorang untuk dapat menguasai informasi dan pengetahuan yang ada (Hermawan, 2007, p.41) sehingga diperlukan suatu kemampuan memperoleh, memilih, dan mengelola informasi. Kemampuan-kemampuan tersebut harus didasari oleh pemikiran yang kritis, sistematis, dan logis, karena kemampuan tersebut sangat penting dalam menganalisa, mengevaluasi segala argumen untuk mampu membuat keputusan yang rasional dan bertanggungjawab. Oleh karena itu diperlukan suatu program pendidikan yang dapat mengembangkan kemampuan berpikir kritis, sistematis dan logis. Salah satu program pendidikan yang dapat mengembangkan kemampuan tersebut adalah matematika.

Melihat pentingnya matematika dan peranannya dalam menghadapi kemajuan ilmu pengetahuan dan teknologi serta persaingan global maka peningkatan mutu pendidikan matematika di semua jenis dan jenjang pendidikan harus selalu diupayakan. Salah satu upaya yang dapat dilakukan adalah dengan menyempurnakan kurikulum pendidikan. Pada Kurikulum Tingkat Satuan Pendidikan (KTSP), tujuan yang ingin dicapai melalui pembelajaran matematika di jenjang SMP adalah: (1) Memahami konsep matematika, menjelaskan keterkaitan antar konsep dan mengaplikasikan konsep atau algoritma, secara luwes, akurat, efisien, dan tepat, dalam pemecahan masalah, (2) Menggunakan penalaran pada pola dan sifat, melakukan manipulasi matematika dalam membuat generalisasi, menyusun bukti, atau menjelaskan gagasan dan pernyataan matematika, (3) Memecahkan masalah yang meliputi kemampuan memahami masalah, merancang model matematika, menyelesaikan model dan menafsirkan solusi yang diperoleh, (4) Mengomunikasikan gagasan dengan simbol, tabel, diagram, atau media lain untuk memperjelas keadaan atau masalah, (5) Memiliki sikap menghargai kegunaan matematika dalam kehidupan, yaitu memiliki rasa ingin tahu, perhatian, dan minat dalam mempelajari matematika, serta sikap ulet dan percaya diri dalam pemecahan masalah. (Depdiknas, 2006, p.346).

Berdasarkan tujuan tersebut, setidaknya terdapat beberapa kompetensi yang diharapkan dimiliki oleh siswa setelah mempelajari matematika, diantaranya: menggunakan penalaran pada pola dan sifat, melakukan manipulasi matematika dalam membuat generalisasi, menyusun bukti, serta mampu mengkomunikasikan gagasan atau ide-ide matematika.

Namun, fakta di lapangan selalu ada masalah dalam mencapai tujuan tesebut dan sulit untuk meningkatkan mutu pendidikan. Selanjutnya, masalah itu pun, bukan hanya terjadi dalam ruang lingkup yang besar, melainkan terjadi dalam ruang lingkup yang lebih kecil, seperti di SMP Negeri 7 Yogyakarta. Adapun beberapa masalah tersebut, antara lain: prestasi belajar matematika siswa masih tergolong rendah, kemampuan komunikasi matematika masih rendah, metode siswa masih belum berkembang dengan baik.

Hermawan (2007, p.42) menyatakan salah satu penyebab rendahnya kualitas pemahaman siswa dalam matematika menurut hasil survey IMSTEP-JICA adalah bahwa dalam pembelajaran matematika guru terlalu berkonsentrasi pada hal-hal yang prosedural dan mekanistik, pembelajaran berpusat pada guru, konsep matematika disampaikan secara informatif, siswa dilatih menyelesaikan banyak soal tanpa pemahaman yang mendalam. Akibatnya, kemampuan kompetensi strategis siswa tidak berkembang. Berdasarkan data hasil Ulangan Harian siswa SMP Negeri 7 Yogyakarta tiga tahun terakhir khususnya pada materi bangun ruang sisi datar diketahui pada tahun pelajaran 2010/2011 nilai ratarata 6,07, pada tahun pelajaran 2011/2012 nilai rata-rata 7,10 dan pada tahun pelajaran 2012/ 2013 nilai rata-rata 5,21. Berdasarkan data tersebut diketahui bahwa pada tahun 2012/2013 mengalami penurunan yang signifikan dibandigkan dengan tahun pelajaran sebelumnya. Hal ini mengindikasikan adanya penurunan kompetensi yang dimiliki siswa.

Selanjutnya diketahui bahwa nilai kemampuan komunikasi matematika siswa tiga tahun terakhir masih rendah. Pada tahun pelajaran 2010/2011 nilai rata-rata 5,00, pada tahun pelajaran 2011/2012 nilai rata-rata 6,13 dan pada tahun pelajaran 2012/2013 nilai ratarata 5,21. Hal ini disebabkan karena dalam proses pembelajaran guru belum melatih siswa untuk mengerjakan soal-soal yang dapat memunculkan komunikasi matematika, siswa tidak dituntut untuk mengevaluasi dan menjelaskan alasan atas jawaban yang diberikan. Berkaitan dengan kemampuan berpikir matematis siswa, berdasarkan hasil observasi yang dilakukan peneliti pada kelas VIII A dan VIII B SMPM Negeri Yogyakarta diketahui bahwa guru juga belum mengajarkan atau mengembangkan berpikir matematis siswa, guru tidak memberikan 
masalah yang dapat memunculkan metode matematika siswa, sehingga siswa kesulitan dalam menyelesaikan masalah yang diberikan.

Menyikapi permasalahan yang berkaitan dengan kondisi kegiatan pembelajaran di kelas, ketercapaian standar kompetensi, kemapuan komunikasi matematika, dan berpikir matematis siswa, maka perlu upaya perbaikan dan inovasi dalam proses pembelajaran. Salah satu upaya pembenahan dalam rangka meningkatkan kemampuan (ketercapaian standar kompetensi), komunikasi, dan berpikir matematis siswa difokuskan pada pemberian kesempatan siswa untuk membangun pengetahuannya secara aktif, artinya pengetahuan ditemukan, dibentuk, dan dikembangkan oleh siswa sendiri baik secara individu maupun kelompok dengan menggunakan pembelajaran cooperative learning.

Melalui pembelajaran cooperative learning diharapkan di kelas siswa aktif secara individu, aktif berdiskusi, berani menyampaikan gagasan dan menerima gagasan dari orang lain, kreatif mencari solusi dari suatu permasalahan yang dihadapi, memiliki berpikir matematis dan kepercayaan diri yang tinggi dalam pembelajaran matematika, karena pembelajaran cooperative learning dapat meningkatkan prestasi belajar (ketercapaian standar kompetensi). Begitu juga pada aspek komunikasi, dan berpikir matematis siswa.

Dua tipe pembelajaran cooperative learning yang menyenangkan dan mengaktifkan siswa adalah pembelajaran dengan teknik student Teams Achievement (STAD) Division dan Think Pair Share (TPS). Pembelajaran dengan teknik STAD dan TPS adalah pembelajaran yang merangsang aktivitas siswa untuk berfikir dan mendiskusikan hasil pemikirannya dengan teman, dan juga merangsang keberanian siswa untuk mengemukakan pendapatnya di depan kelas.

Cooperative learning type Student Team Achievement Division (STAD) yang dikembangkan oleh Robert Slavin dan teman-temannya di Universitas John Hopkin tahun 1980 merupakan pembelajaran kooperatif yang paling sederhana, dan merupakan pembelajaran kooperatif yang cocok digunakan oleh guru yang baru mulai menggunakan pembelajaran kooperatif. Arends \& Kilcher (2010, p.317), menjelaskan, "STAD involves students working together in groups and groups that compete with each other". STAD melibatkan siswa bekerja bersama dalam kelompok dan masing-masing kelompok bersaing dengan yang lain. Bagian yang paling esensial dari cooperative learning tipe STAD adalah adanya kerjasama anggota kelompok dan kompetisi antar kelompok. Siswa bekerja dalam kelompok untuk belajar dari temannya serta mengajar temannya.

Menurut Majoka (2010, p.6), Student Team Achievement Division (STAD) is a cooperative-learning strategy in which small groups of learners with different levels of ability work together to accomplish a shared learning goal. Pernyataan diatas menjelaskan bahwa Student Team Achievement Division (STAD) adalah strategi pembelajaran kooperatif dimana siswa belajar pada kelompok-kelompok kecil dengan berbagai tingkat kemampuan dan bekerja sama untuk mencapai tujuan belajar bersama. Selanjutnya Borich (2007, p.388) menjelaskan,

in Student Teams-Achievement Division (STAD), the teacher assigns students to 4- or 5-member learning teams. Each team is as heterogeneous as possible to represent the composition of the entire class (boys/girls, higher performing/lower performing, etc.)

Pada STAD, seorang guru menempatkan 4 sampai 5 siswa dalam kelompok belajar. Anggota tiap tim heterogen yang mewakili komposisi dari isi kelas (Laki-laki/perempuan, berkemampuan tinggi/berkemampuan rendah, dan lain-lain). Pendapat di atas mempertegas bahwa dalam STAD, secara khusus siswa bekerja dalam kelompok-kelompok yang heterogen, siswa yang pintar berperan sebagai tutor bagi siswa yang berkemampuan rendah, antara siswa satu dengan siswa yang lainnya saling berbagi dan mengumpulkan informasi, saling membantu untuk berlajar dan bertanggung jawab atas pelajaran anggota kelompok lainnya sebagaimana terhadap dirinya sendiri.

Slavin (1995, p.5) menjelaskan bahwa,

in STAD, student are assigned to fourmember learning teams that are mixed in performance level, gender, and ethnicity. The teacher present a lesson, and then students work within their teams to make sure all team members have mastered the lesson. Then, all students take individual quizzes in on the material, at which time they may not help one another.

Pernyataan tersebut menjelaskan bahwa dalam STAD, siswa dibagi dalam kelompok belajar yang terdiri atas empat orang yang berbeda tingkat kemampuan, jenis kelamin dan etniknya. Guru menyampaikan pelajaran, lalu 
siswa diarahkan untuk bekerja dalam kelompok mereka dan memastikan bahwa semua anggota kelompok telah menguasai materi yang ditugaskan. Selanjutnya semua siswa mengerjakan kuis mengenai materi secara sendiri-sendiri, dimana saat itu mereka tidak diperbolehkan untuk saling membantu.STAD memiliki lima tahapan pembelajaran yang dapat mengaktifkan siswa dalam proses belajar mengajar yaitu presentasi kelas, kerja kelompok, kuis, peningkatan skor individu dan rekognisi tim.

Mengajukan pertanyaan selama pembelajaran di kelas adalah cara yang tepat untuk mengaktifkan siswa, mengukur pemahaman siswa, atau mengarahkan siswa dalam menerapkan pengetahuan baru. Salah satu strategi yang memadukan pola berpikir individu dan kelompok adalah Think-Pair-Share (TPS). Strategi ini dikembangkan oleh Frank Lyman dari university of Maryland (Slavin, 1995, p.132).

Pembelajaran Think-Pair-Share memiliki prosedur yang diterapkan secara eksplisit untuk memberikan siswa waktu lebih banyak untuk berfikir, menjawab dan saling membantu satu sama lain. Pada strategi ini guru hanya berperan sebagai fasilitator sehingga guru menyajikan satu materi dalam waktu pembahasan yang relatif singkat. Setelah itu giliran siswa untuk memikirkan secara mendalam tentang apa yang telah dijelaskan

$$
\text { Arra, D'Antonio (2011, p.115) }
$$

menyatakan:

In this approach (Think-Pair-Share), the instructor poses a problem with many possible answers. The students write an answer and pass the sheet amongst the group. Finally, the group discusses all possible answers on the sheet.

Berdasarkan pernyataan diatas diketahui bahwa dalam Think-Pair-Share, instruktur memberikan pertanyaan ke kelas, siswa berpikir tentang pertanyaan, dan siswa berbagi pikiran mereka dengan siswa lain. Oleh karena itu diharapkan siswa dapat aktif pada saat proses belajar mengajar berlangsung sehingga diskusi kelompok yang dilakukan dapat memberikan dampak positif dalam pembelajaran dikelas.

Terkait penerapan think-pair-share, Slavin (1995, p.132) menjelasan bahwa,

when the teacher presents a lesson to the class, student sit in pairs within their teams. The teacher poses questions to the class. Students are instructed to think of an answer on their own, then to pair with their partner to reach consensus on an answer. Finally, the teacher asks students to share their agreed-upon answer with the rest of the class.

Pernyataan tersebut menjelaskan bahwa ketika guru mengajar di kelas, siswa diarahkan untuk duduk berpasangan dalam timnya. Kemudian guru mengajukan pertanyaan. Siswa diarahkan untuk memikirkan sebuah jawaban mereka sendiri, kemudian siswa duduk berpasangan dengan pasangannya untuk memperoleh jawaban yang disepakati berdua. Terakhir guru meminta siswa untuk berbagi pendapat dengan kelompok lain dalam kelas.

Kinzie \& Markovchick (2005, p.67) menjelaskan,

think-Pair-Share: This strategy is designed to encourage student involvement. First, participants listen to the teacher's question. Then they think of a response. They pair up with someone and discuss their responses. Finally, they are asked to share their responses with the whole group. Usually a time limit is set for each step.

Deskripsi tersebut menjelaskan bahwa Think-Pair-Share merupakan strategi yang dirancang untuk mendorong keterlibatan siswa. Tahap pertama, siswa mendengarkan pertanyaan guru. Kemudian memikirkan sebuah jawabannya. Mereka berpasangan dengan seorang siswa lainnya dan mendiskusikan jawaban mereka. Terakhir, mereka diminta untuk menjelaskan/ berbagi jawaban dengan kelompok lain.

Kompetensi dalam bidang matematika merupakan kemampuan unjuk kerja keahlian, yang dibentuk melalui pengetahuan, keterampilan dan pembinaan sikap tentang matematika. Kompetensi matematika seseorang dapat dilihat dari kemampuannya memenuhi tuntutan spesifikasi pekerjaan, atau kemampuan tingkah laku unjuk kerja dalam menangani pekerjaan dalam kegiatan matematika.

Maton \& Moore (2010, p.104) mendefinisikan kompetensi sebagai: "competency comprises the specification of knowledge and skill and the application of that knowledge and skill to the standard of performance required in the workplace". Pendapat tersebut menjelaskan bahwa kompetensi didefenisikan sebagai spesifikasi pengetahuan dan keterampilan serta penerapannya dengan standar kinerja yang dibutuhkan di tempat kerja. Sedangkan menurut Young (1998, 
p.75), "competencies-are defined in terms of observable performances". Secara singkat dijelaskan bahwa kompetensi adalah suatu istilah dari kinerja yang diamati.

Standar diartikan sebagai "ukuran" yang disepakati, sedangkan kompetensi telah didefinisikan sebagai kemampuan seseorang yang dapat terobservasi mencakup atas pengetahuan, keterampilan dan sikap dalam menyelesaikan suatu pekerjaan atau tugas sesuai dengan standar performa yang ditetapkan. Oleh karena itu dapatlah disepakati bahwa standar kompetensi merupakan kesepakatan-kesepakatan tentang kompetensi yang diperlukan pada suatu bidang pekerjaan oleh seluruh "stakeholder" di bidangnya DIKTI (2011, p.29).

Pendapat lain dalam Permendiknas nomor 22 tahum 2006 menyatakan standar kompetensi adalah kualifikasi kemampuan minimal peserta didik yang menggambarkan penguasaan sikap, pengetahuan dan keterampilan yang diharapkan dicapai pada setiap tingkat dan/atau semester, standar kompetensi terdiri atas sejumlah kompetensi dasar sebagai acuan baku yang harus dicapai dan berlaku secara nasional. Sehingga dengan kata lain, yang dimaksud dengan standar kompetensi adalah perumusan tentang kemampuan yang harus dimiliki seseorang untuk melakukan suatu tugas atau pekerjaan yang didasari atas pengetahuan, keterampilan dan sikap kerja sesuai dengan unjuk kerja yang dipersyaratkan.

Permendiknas No. 41 tahun 2007 menjelaskan bahwa standar kompetensi adalah kualifikasi kemampuan minimal peserta didik yang menggambarkan penguasaan pengetahuan, sikap, dan keterampilan yang diharapkan dicapai pada setiap kelas dan/atau semester pada suatu mata pelajaran.

Kompetensi dan pengukuran hasil belajar berhubungan erat, pada akhir pembelajaran baik pengajar maupun siswa ingin tahu bagaimana hasil pembelajaran itu, secara sederhana mereka ingin mengetahui bagaimana nilai yang dicapai. Untuk menjawab pertanyaan itu guru perlu membuat alat pengukuran yang dapat mengukur penguasaan kompetensi yang dimaksud dalam tujuan pembelajaran.

Komunikasi merupakan salah satu standar kompetensi lulusan bagi siswa sekolah dasar sampai menengah yang tertuang dalam Permendiknas nomor 23 tahun 2006 tentang standar kompetensi lulusan. Oleh karena itu, komunikasi dalam matematika perlu mendapat perhatian serius untuk meningkatkan hasil belajar siswa. Melalui komunikasi, ide-ide menjadi objek refleksi, perbaikan, diskusi, dan pengembangan. Lee (2006, p.69) menjelaskan bahwa:

By communicating their ideas as they
learn they will become able to use and
control mathematical concepts with more
confidence then the presently do. How-
ever, they pupils must take on a different
role in mathematics class roomand so
must the teacher. Pupils must be involved
in and responsible for their own learning
and teachers must help them to be able to
do this. Teachers can accomplish this in
several ways: By changing the was in the
which pupils interact with the work and
each other; by giving them more
challenging problems to solve; and by
asking them to express their mathema-
tical ideas in writing

Mengkomunikasikan ide-ide siswa saat mereka belajar menyebabkan mereka bisa menggunakan dan mengontrol konsep-konsep matematika dengan keyakinan yang lebih dari yang mereka lakukan saat ini. Siswa harus mengambil peran yang berbeda dalam kelas matematika dan demikian juga dengan guru. Siswa harus terlibat dan bertanggung jawab terhadap belajar mereka sendiri, sedangkan guru harus membantu mereka untuk bisa melakukannya. Guru dapat melakukan tugasnya melalui beberapa cara: mengubah cara siswa berinteraksi dengan pekerjaan dan satu sama lain; memberikan mereka masalah yang lebih menantang untuk dipecahkan, dan meminta mereka untuk mengekspresikan ide-ide matematika secara tertulis. Menurut Los Angeles County Office of Education (Mahmudi, 2009, p.3) terdapat berbagai bentuk komunikasi komunikasi matematis yaitu (a) merefleksi dan mengklarifikasi pemikiran tentang ide-ide matematika; (b) menghubungkan bahasa sehari-hari dengan bahasa matematika yang menggunakan simbol-simbol; (c) menggunakan keterampilan membaca, mendengarkan, menginterpretasikan, dan mengevaluasi ide-ide matematika; dan (d) menggunakan ide-ide matematika untuk membuat dugaan (conjecture) dan membuat argumen yang meyakinkan.

Lebih lanjut Los Angeles County Office of Education (LACOE) menyatakan bahwa komunikasi matematis mencakup komunikasi tertulis maupun lisan atau verbal. Komunikasi tertulis dapat berupa penggunaan kata-kata, gambar, tabel, dan sebagainya yang menggam- 
barkan proses berpikir siswa. Komunikasi tertulis juga dapat berupa uraian pemecahan masalah atau pembuktian matematika yang menggambarkan kemampuan siswa dalam mengorganisasi berbagai konsep untuk menyelesaikan masalah. Sedangkan komunikasi lisan dapat berupa pengungkapan dan penjelasan verbal suatu gagasan matematika. Komunikasi lisan dapat terjadi melalaui interaksi antarsiswa misalnya dalam pembelajaran dengan setting diskusi Kelompok.

Stacey (2007, p.40) mendefinisikan proses berpikir matematika sebagai berikut,

mathematical thinking process consist of: (1). Specializing (trying special cases, looking at examples), (2). Generalizing (looking for patterns and relationships), (3). conjecturing (predicting relationships and results), and (4). convincing (finding and communicating reason why something is true).

Proses berpikir matematika terdiri dari spesialisasi (mencoba kasus khusus, melihat contoh-contoh), generalisasi (mencari pola-pola dan hubungan), menduga (memprediksi hubungan dan hasil), dan meyakinkan (menemukan dan mengkomunikasikan alasan mengapa sesuatu itu benar).

Upaya untuk memunculkan berpikir matematis siswa pada pembelajaran matematika dapat menggunakan masalah-masalah kontekstual sebagai materi pengantar. Masalah-masalah kontekstual adalah soal-soal cerita yang berkaitan dengan masalah yang ditemui dalam kehidupan nyata setiap hari. Sebagaimana yang dijelaskan Bonomo, (2007, p.319), bahwa "mathematics would have to be applied to natural situations, in which there appear real problems, and to solve it is necessary the use of the mathematical method". Kalimat di atas menjelaskan bahwa matematika seharusnya diterapkan pada situasi alami, di mana akan muncul masalah nyata, dan untuk menyelesaikannya diperlukan penggunaan berpikir matematis.

Katagiri, (2007, pp.117-118) menjelaskan secara detail bahwa mathematical thinking terkait dengan metode matematika mencakup:

Mathematical thinking related to mathematical methods is inductive thinking, analogical thinking, deductive thinking, integrative thinking (including expansive thinking), developmental thinking, abstract thinking (thinking that abstracts, concretizes, idealizes, and thinking that clarifiesconditions), thinking that simplifies, thinking that generalizes, thinking that specializes, thinking that symbolize, thinking that express with numbers, quantifies, and figures.

Pernyataan tersebut menjelaskan bahwa mathematical thinking terkait metode matematika mencakup berpikir induktif, analogi, deduktif, integrasi, pemikiran mengembangkan, abstraksi, menyederhanakan, generalisasi, mengkhususkan, menyimbolkan, dan menyatakan dengan angka, jumlah, dan gambar/bangun. Sedangkan menurut Arcavi (2007, p.2), yang termasuk berpikir matematis adalah "mathematical methods consists of: inductive and deductive reasoning, analogical thinking, generalization, specialization, symbolization". Menjelaskan bahwa berpikir matematis terdiri dari penalaran induktif dan deduktif, bepikir analogi, generalisasi, spesialisasi, dan simbolisasi. Seorang guru harus mampu menciptakan suasana pembelajaran yang membuat siswanya dapat mengeksplorasi kemampuan berpikirnya sehingga dapat melatih berpikir matematis siswa. Berdasarkan beberapa pendapat di atas, dapat disimpulkan bahwa berpikir matematis adalah proses berpikir matematika dengan menggunakan prinsip-prinsip matematika dalam menyelesaikan permasalahan matematika.

Berdasarkan uraian-uraian tersebut, maka yang menjadi tujuan penelitian ini adalah mendeskripsikan keefektifan pembelajaran cooperative learning (student team achievement division dan think-pair-share) dan keefektifan metode student team achievement division dibandingan dengan metode think-pair-share ditinjau dari aspek ketercapaian standar kompetensi, kemampuan komunikasi matematika, dan berpikir matematis siswa SMP. Dan diharapkan dengan adanya penelitian ini akan mampu memberikan sumbangan dalam pembelajaran matematika, terutama yang berkaitan dengan pembelajaran cooperative learning type student team achievement division, type think-pairshare, dan bagaimana keefektifan kedua pembelajaran tersebut pada ditinjau dari aspek ketercapaian standar kompetensi, kemampuan komunikasi matematika, dan berpikir matematis siswa SMP.

\section{METODE}

Jenis penelitian ini adalah eksperimen semu (quasi experiment) dengan desain pretestposttest nonequivalent comparison-group design. Penelitian ini dilakukan di SMP Negeri 
7 Yogyakarta dari bulan Maret sampai dengan April tahun 2014. Adapun populasinya adalah seluruh siswa Kelas VIII SMP Negeri 7 Yogyakarta Tahun Pelajaran 2013/2014 yang terdiri dari 5 kelas. Dengan memilih secara acak dari keseluruhan siswa keenam kelas tersebut, maka dipilih siswa dari dua kelas saja yang menjadi sampel penelitian, yaitu siswa kelas VIII A dan siswa VIII B.

Variabel bebas dalam penelitian ini adalah pembelajaran cooperative learning (type student team achievement division dan thinkpair-share) dan variabel terikatnya adalah ketercapaian standar kompetensi, kemampuan komunikasi matematika, dan berpikir matematis. Instrumen yang digunakan untuk mengukur ketercapaian standar kompetensi, adalah tes prestasi belajar matematika yang terdiri atas 14 soal uraian. Instrumen yang digunakan untuk mengukur kemampuan komunikasi matematika adalah tes kemampuan komunikasi yang terdiri atas enam soal uraian, dan untuk aspek berpikir matematis instrumen yang digunakan adalah tes dengan tujuh soal uraian dan angket berpikir matematis. yang terdiri atas tiga puluh item yang berbentuk checklist.

Teknik pengumpulan data dilakukan dengan pertama-tama memberikan tes dan angket sebelum perlakuan terhadap sampel yang telah ditentukan. Setelah itu, dilanjutkan dengan pemberian perlakuan berupa penerapan pembelajaran cooperative learning type student team achievement division dan type think-pair-share dan diakhiri dengan pemberian tes dan angket setelah perlakuan terhadap kedua sampel tersebut. Pada penelitian ini, teknik analisis data dilakukan dengan cara mendeskripsikan data dan menganalisis statistik inferensial terhadap data yang diperoleh. Deskripsi data dilakukan dengan mencari rata-rata, standar deviasi, varians, skor minimal, dan skor maksimal dari data yang diperoleh, baik untuk data sebelum perlakuan, maupun untuk data setelah perlakuan.

Untuk menguji apakah pembelajaran cooperative learning (student team achievement division dan think-pair-share) ditinjau dari ketercapaian standar kompetensi, kemampuan komunikasi matematika, dan berpikir matematis siswa SMP digunakan uji one sample t-test dengan formula sebagai berikut:

$$
t=\frac{\bar{x}-\mu_{0}}{\frac{S}{\sqrt{n}}}
$$

dengan: $\bar{x}=$ nilai rata-rata yang diperoleh

$\mu_{0}=$ nilai yang dihipotesiskan (74,99 untuk aspek ketercapaian standar kompetensi, kemampuan komunikasi matematika, dan berpikir matematis dan angket berpikir matematis 100,99)

$S=$ standar deviasi sampel

$n=$ banyak anggota sampel.

Kriteria pengujiannya adalah $\mathrm{H}_{0}$ ditolak jika $t_{\text {hit }}>t_{(\alpha ; n-1)}$.

Untuk data sebelum perlakuan dilakukan uji MANOVA untuk melihat apakah terdapat perbedaan kemampuan awal antara dua kelas sampel ditinjau dari aspek ketercapaian standar kompetensi, kemampuan komunikasi matematika, dan berpikir matematis siswa SMP dengan menggunakan formula sebagai berikut:

$T^{2}=\frac{n_{1} \cdot n_{2}}{n_{1}+n_{2}}\left(\bar{y}_{1}-\bar{y}_{2}\right) S^{\prime-1}\left(\bar{y}_{1}-\bar{y}_{2}\right)$

keterangan:

$T^{2}=$ Hotelling's Trace

$n_{l}=$ banyak anggota sampel I

$n_{2}=$ banyak anggota sampel II

$\bar{y}_{1}-\bar{y}_{2}=$ mean vektor

$S^{-1}=$ invers matriks kovariansi.

Setelah memperoleh nilai $T^{2}$ Hotteling's, selanjutnya nilai tersebut ditransformasikan untuk memperoleh nilai distribusi $F$ dengan formula sebagai berikut:

$$
F=\frac{n_{1}+n_{2}-p-1}{\left(n_{1}+n_{2}-2\right) p} T^{2}
$$

(Stevens, 2009, p.151) dengan:

$p=$ banyaknya variabel terikat.

Kriteria pengujiannya adalah $\mathrm{H}_{01}$ ditolak jika $\left.F_{h i t} \geq F_{(} \alpha ; p ; n l+n 2-p-1\right)$.

Setelah diketahui bahwa tidak terdapat perbedaan kemampuan awal antara kedua kelas sampel, maka untuk data tes dan angket setelah perlakuan pun dilakukan uji untuk melihat apakah terdapat perbedaan keefektifan pembelajaran cooperative learning (student team achievement division dan think-pair-share ditinjau dari aspek ketercapaian standar kompetensi, kemampuan komunikasi matematika, dan berpikir matematis dengan menggunakan rumus MANOVA (2) dan (3). Setelah diketahui bahwa terdapat perbedaan keefektifan, maka terhadap data tersebut dilakukan uji $t$-Benferroni untuk melihat apakah pembelajaran cooperative learning type student team achievement division lebih efektif daripada type think-pair-share 
ditinjau dari ketiga aspek tersebut dengan menggunakan formula sebagai berikut:

$$
t=\frac{\bar{y}_{1}-\bar{y}_{2}}{\sqrt{\frac{\left(n_{1}-1\right) s_{1}^{2}+\left(n_{2}-1\right) s_{2}^{2}}{n_{1}+n_{2}-2}\left(\frac{1}{n_{1}}+\frac{1}{n_{2}}\right)}}
$$

(Stevens, 2009, p.147)

Keterangan:

$\bar{y}_{1}=$ nilai rata-rata sampel I

$\bar{y}_{1}=$ nilai rata-rata sampel II

$S_{1}^{2}=$ varians sampel I

$S_{2}^{2}=$ varians sampel II

$n_{l}=$ banyak anggota sampel I

$n_{2}=$ banyak anggota sampel II.

Kriteria pengujiannya adalah $\mathrm{H}_{02}, \mathrm{H}_{03}$, dan $\mathrm{H}_{04}$ ditolak jika $t_{\text {hit }} \geq t_{\left(\frac{\alpha}{p} ; n 1+n 2-2\right)}$.

Akan tetapi, sebelum melakukan analisis di atas, terlebih dahulu dilakukan uji asumsi terhadap data ketercapaian standar kompetensi, kemampuan komunikasi matematika, dan berpikir matematis siswa SMP yaitu uji normalitas multivariat dan uji homogenitas matriks kovarians, baik untuk data sebelum dan setelah perlakuan. Uji normalitas multivariat dilakukan menggunakan uji jarak Mahalanobis $\left(d_{i}^{2}\right)$ dengan kriteria keputusan bahwa data dikatakan berdistribusi normal jika sekitar $50 \%$ data mempunyai nilai $d_{i}^{2}<\chi_{(p ; 0,5)}^{2}$ Uji homogenitas matriks kovarians dilakukan dengan menggunakan uji Box's $M$ dengan kriteria keputusan bahwa data dikatakan homogen jika nilai signifikansi $F$ lebih besar dari 0,05.

\section{HASIL DAN PEMBAHASAN}

Pelaksanaan pendekatan pembelajaran cooperative learning (type student team achivement division dan think-pair-share) pada penelitian ini sudah berjalan sesuai dengan kegiatan pembelajaran yang sudah ditetapkan. Meskipun semua kegiatan pembelajaran tersebut sudah dilaksanakan tetapi ditemukan beberapa keterbatasan yang menjadi kendala pada pelaksanaan penelitian ini, terutama pada pertemuanpertemuan awal, seperti: alokasi waktu antarkegiatan pembelajaran kurang diperhatikan, siswa cenderung takut dalam memberikan tanggapan pada saat kegiatan presentasi kelas dilaksanakan.

Deskripsi data ketercapaian standar kompetensi, baik untuk kelas student tema achievement division (STAD), maupun untuk kelas think-pair-share (TPS) bisa dilihat pada Tabel 1.
Tabel 1. Deskripsi Data Ketercapaian Standar Kompetensi

\begin{tabular}{ccccc}
\hline \multirow{2}{*}{ Deskripsi } & \multicolumn{2}{c}{ STAD } & \multicolumn{2}{c}{ TPS } \\
\cline { 2 - 5 } & Awal & Akhir & Awal & Akhir \\
\hline Rata-rata & 51,52 & 85,66 & 54,02 & 78,68 \\
Nilai Maksimum & & & & \\
Teoretik & 100 & 100 & 100 & 100 \\
Nilai Minimum & & & & \\
Teoretik & 0 & 0 & 0 & 0 \\
Nilai Maksimum & 69,41 & 100 & 74,67 & 88,66 \\
Nilai Minimum & 38,82 & 69,07 & 38,67 & 46,39 \\
Standar Deviasi & 7,35 & 7,10 & 8,27 & 9,11 \\
\hline
\end{tabular}

Berdasarkan Tabel 1, diperoleh informasi bahwa nilai rata-rata ketercapaian standar kompetensi siswa, baik untuk kelas STAD, maupun kelas TPS sebelum perlakuan belum mencapai nilai rata-rata 75 dan setelah perlakuan sudah mencapai nilai rata-rata di atas 75 .

Deskripsi data kemampuan komunikasi matematika, baik untuk kelas STAD, maupun untuk kelas TPS bisa dilihat pada Tabel 2.

Tabel 2. Deskripsi Data Kemampuan Komunikasi matematika

\begin{tabular}{ccccc}
\hline \multirow{2}{*}{ Deskripsi } & \multicolumn{2}{c}{ STAD } & \multicolumn{2}{c}{ TPS } \\
\cline { 2 - 5 } & Awal & Akhir & Awal & Akhir \\
\hline Rata-rata & 41,52 & 88,99 & 43,21 & 82,47 \\
$\quad$ Nilai & & & & \\
Maksimum & & & & \\
$\quad$ Teoretik & 100 & 100 & 100 & 100 \\
Nilai Minimum & & & & \\
$\quad$ Teoretik & 0 & 0 & 0 & 0 \\
$\quad$ Nilai & & & & \\
Maksimum & 79,49 & 98,72 & 69,23 & 100 \\
Nilai Minimum & 7,69 & 71,79 & 19,23 & 51,28 \\
$\begin{array}{c}\text { Standar Deviasi } \\
\text { Variansi }\end{array}$ & 12,57 & 8,23 & 14,38 & 12,60 \\
$\quad 158,09$ & 67,75 & 206,75 & 158,66 \\
\hline
\end{tabular}

Berdasarkan Tabel 2, diperoleh informasi bahwa nilai rata-rata kemampuan komunikasi matematika siswa, baik untuk kelas STAD, maupun kelas TPS sebelum perlakuan belum mencapai nilai rata-rata 75 dan setelah perlakuan sudah mencapai nilai rata-rata di atas 75 .

Deskripsi data berpikir matematis siswa terhadap proses pembelajaran matematika, baik untuk kelas STAD, maupun untuk kelas TPS bisa dilihat pada Tabel 3 . 
Tabel 3. Deskripsi Data Berpikir matematis Siswa

\begin{tabular}{ccccc}
\hline \multirow{2}{*}{ Deskripsi } & \multicolumn{2}{c}{ Kelas STAD } & \multicolumn{2}{c}{ Kelas TPS } \\
\cline { 2 - 5 } & Awal & Akhir & Awal & Akhir \\
\hline Rata-rata & 39,03 & 86,43 & 40,04 & 81,34 \\
$\quad$ Nilai & & & & \\
Maksimum & & & & \\
Teoretik & 100 & 100 & 100 & 100 \\
$\begin{array}{c}\text { Nilai Minimum } \\
\text { Teoretik } \\
\text { Nilai }\end{array}$ & 0 & 0 & 0 & 0 \\
Maksimum & 59,70 & 100 & 71,64 & 94,29 \\
Nilai Minimum & 13,43 & 58,57 & 16,42 & 62,86 \\
Standar Deviasi & 10,73 & 10,07 & 13,71 & 8,29 \\
Variansi & 115,18 & 101,45 & 187,86 & 68,76 \\
\hline
\end{tabular}

Tabel 3 menunjukkan bahwa rata-rata jumlah skor berpikir matematis siswa terhadap proses pembelajaran matematika, baik untuk kelas STAD, maupun kelas TPS sebelum perlakuan belum mencapai rata-rata skor 75 dan setelah perlakuan sudah mencapai rata-rata skor di atas 75 .

Uji normalitas dan homogenitas data ketercapaian standar kompetensi, kemampuan komunikasi matematika, dan berpikir matematis siswa untuk sebelum dan setelah perlakuan, baik untuk kelas STAD, maupun untuk kelas TPS secara berturut-turut bisa dilihat pada Tabel 4 dan Tabel 5.

Tabel 4. Hasil Uji Normalitas

\begin{tabular}{ccc}
\hline Kelas & $\begin{array}{c}d_{i}^{2} \text { Sebelum } \\
\text { Perlakuan }\end{array}$ & $\begin{array}{c}d_{i}^{2} \text { Setelah } \\
\text { Perlakuan }\end{array}$ \\
\hline STAD & $55,88 \%$ & $50,00 \%$ \\
TPS & $50,00 \%$ & $52,94 \%$ \\
\hline
\end{tabular}

Tabel 4 memperlihatkan bahwa sekitar $50 \%$ data mempunyai nilai $d_{i}^{2}<\chi_{(3 ; 0,5)}^{2}$. Atau dengan kata lain, data ketercapaian standar kompetensi, data kemampuan komunikasi matematika, dan berpikir matematis untuk sebelum dan setelah perlakuan, baik untuk kelas STAD, maupun untuk kelas TPS sudah memenuhi asumsi normalitas.

Tabel 5. Hasil Uji Homogenitas

\begin{tabular}{ccc}
\hline & $\begin{array}{c}\text { Sebelum } \\
\text { Perlakuan }\end{array}$ & $\begin{array}{c}\text { Setelah } \\
\text { Perlakuan }\end{array}$ \\
\hline Box's $M$ & 5,850 & 10,696 \\
$F$ & 0,927 & 1,695 \\
Sig. & 0,474 & 0,118 \\
\hline
\end{tabular}

Berdasarkan Tabel 5, diperoleh informasi bahwa nilai signifikansi $F$ lebih besar dari 0,05 atau dengan kata lain, data ketercapaian standar kompetensi, kemampuan komunikasi matema- tika, dan berpikir matematis untuk sebelum dan setelah perlakuan sudah memenuhi asumsi homogenitas.

Hasil uji mengenai keefektifan pembelajaran cooperative learning (type STAD dan TPS) ditinjau dari aspek ketercapaian standar kompetensi, kemampuan komunikasi matematika, dan berpikir matematis dapat dilihat pada Tabel 6.

Tabel 6. Hasil Uji One Sample t-test

\begin{tabular}{ccccc}
\hline \multirow{2}{*}{ Aspek } & \multicolumn{2}{c}{$\boldsymbol{S T A D}$} & \multicolumn{2}{c}{ TPS } \\
\cline { 2 - 5 } & $\mathbf{t}_{\text {hit }}$ & Sig. & $\mathbf{t}_{\text {hit }}$ & Sig. \\
\hline $\begin{array}{c}\text { Ketercapaian } \\
\text { Standar }\end{array}$ & 10,296 & 0,000 & 10,296 & 0,000 \\
$\begin{array}{c}\text { Kompetensi } \\
\text { Kemampuan }\end{array}$ & & & & \\
$\begin{array}{c}\text { Komunikasi } \\
\text { Matematika } \\
\text { Berpikir } \\
\text { matematis } \\
\text { Angket } \\
\text { Berpikir }\end{array}$ & 9,917 & 0,000 & 3,462 & 0,002 \\
matematis & 4,488 & 0,000 & 2,578 & 0,015 \\
\hline
\end{tabular}

Berdasarkan Tabel 6, diperoleh informasi bahwa nilai signifikansi $t$ untuk semua aspek lebih kecil dari 0,05. Artinya, $\mathrm{H}_{\mathrm{o}}$ ditolak atau dengan kata lain, pembelajaran cooperative learning type STAD dan TPS efektif ditinjau dari aspek ketercapaian standar kompetensi, kemampuan komunikasi, dan berpikir matematis. Hasil di atas kemudian sejalan dengan kajian teori yang mengungkapkan bahwa kedua pembelajaran cooperative learning tersebut ditinjau dari ketiga aspek yang diukur. Hal ini disebabkan karena pada pembelajaran cooperative learning type STAD siswa aktif dalam berdiskusi menyelesaikan masalah, terbentuk ketergantungan positif pada masing-masing siswa untuk terus meningkatkan pemahaman dan prestasinya agar kelompok mereka mendapatkan penghargaan yang baik.

Pada pembelaran cooperative learning type STAD, siswa terlibat langsung dalam pembelajaran, mulai dari siswa memahami masalah, sampai dengan siswa menemukan konsep yang terkandung dalam masalah tersebut. Keterlibatan tersebut, bukan hanya sampai pada menemukan konsep, melainkan juga berlanjut pada kegiatan diskusi kelas, baik diskusi tentang penemuan konsep, maupun diskusi tentang hasil pengerjaan contoh dan latihan soal di depan kelas. Siswa pada kegiatan diskusi boleh memberikan tanggapan, pertanyaan, dan bahkan jawaban terkait dengan yang disampaikan siswa tertentu di 
depan kelas. Hal ini kemudian membuat siswa, bukan hanya terampil dalam menjawab soal, melainkan juga terampil dalam memberikan alasan terkait dengan jawaban yang mereka miliki. Sebagai tambahan, pada setiap pertemuan pada pembelajaran STAD diberikan penghargaan kelompok, dimana setiap siswa turut andil dalam menyumbangkan poin pada kelompoknya. Kelompok yang memiliki nilai rata-rata tertinggi maka akan mendapatkan penghargaan yang baik. Guru memberi tahu kepada setiap siswa siapa saja yang memberikan sumbangan nilai tertinggi dalam kelompoknya, sehingga dapat memotivasi siswa agar lebih giat dan dapat meningkatkan nilainya.

Selain itu, pada pembelajaran cooperative learning type TPS pun, siswa juga diberikan kesempatan untuk menyelesaikan suatu soal yang bersifat masalah. Siswa diberi waktu untuk menyelesaikan masalahnya sendiri (think), disini siswa dapat mengembangkan pemahamannya terhadap masalah yang diberikan. Setidaknya pada tahap think ini siswa sudah memiliki pemahaman dan jawaban sementara terhadap masalah yang diberikan. Selanjutnya, siswa duduk berpasangan (pair) untuk mendiskusikan masalah yang diberikan, menyatukan pemikiran, menemukan konsep, setelah mendapat jawaban dan kesepakatan maka siswa akan mempresentasikan hasil diskusi mereka ke depan kelas (share). Pada tahap share memungkinkan peningkatan pemahaman siswa karena siswa dapat bertanya atas apa yang tidak dipahaminya kepada teman yang presentasi, bertukar ide dan gagasan.

Hasil penelitian ini pun sejalan dengan penelitian yang dilakukan oleh Kaddoura, Mahmoud. (2013, p. 8); Muhammad Iqbal Majoka (2010, p.19); Effandi Zakaria (2010, p.1); Shininger (2006, p.27); Adesoji \& Ibraheem (2009, p. 29); Marsigit (2007, p.15) yang mengungkapkan bahwa pembelajaran cooperative learning (STAD dan TPS) ditinjau dari aspek ketercapaian standar kompetensi, kemampuan komunikasi matematika, dan berpikir matematis.

Hasil uji mengenai apakah terdapat perbedaan kemampuan awal antara kedua kelas sampel sebelum diberikan perlakuan dan perbedaan keefektifan pembelajaran cooperative learning ( type STAD dan TPS) ditinjau dari ketercapaian standar kompetensi, kemampuan komunikasi matematika, dan berpikir matematis dapat dilihat pada Tabel 7.
Tabel 7. Hasil MANOVA Data Sebelum dan Setelah Perlakuan

\begin{tabular}{ccc}
\hline & $\boldsymbol{F}$ & Sig. \\
\hline Kelas (Sebelum Perlakuan) & 0,629 & 0,599 \\
Kelas (Setelah Perlakuan) & 9,227 & 0,000 \\
\hline
\end{tabular}

Berdasarkan Tabel 7, diperoleh informasi bahwa nilai signifikansi $F$ lebih besar dari 0,05 untuk data sebelum perlakuan dan lebih kecil dari 0,05 untuk data setelah perlakuan. Artinya, untuk sebelum perlakuan, tidak terdapat perbedaan kemampuan awal antara kelas STAD dengan TPS ditinjau dari aspek ketercapaian standar kompetensi, kemampuan komunikasi, dan berpikir matematis. Setelah perlakuan, terdapat perbedaan keefektifan pembelajaran cooperative lerning (type STAD dengan type TPS) ditinjau dari aspek ketercapaian standar kompetensi, kemampuan komunikasi, dan berpikir matematis.

Setelah diketahui bahwa terdapat perbedaan keefektifan antara kedua metode pembelajaran, maka akan dilakukan uji t-Benferroni untuk melihat bahwa pembelajaran cooperative learning type STAD lebih efektif daripada pembelajaran cooperative learning type TPS ditinjau dari aspek ketercapaian standar kompetensi, kemampuan komunikasi matematika, dan berpikir matematis. Hasil uji $t$-Benferroni bisa dilihat pada Tabel 8 .

Tabel 8. Hasil Uji t-Benferroni

\begin{tabular}{|c|c|c|}
\hline Aspek & $\begin{array}{c}t- \\
\text { Benferroni } \\
\end{array}$ & $t\left(\frac{\infty}{\left.p^{\prime n 1} 1+n 2-2\right)}\right.$ \\
\hline Ketercapaian SK & 3,52 & 2,17 \\
\hline $\begin{array}{l}\text { Kemampuan } \\
\text { Komunikasi }\end{array}$ & 2,53 & 2,17 \\
\hline $\begin{array}{l}\text { Berpikir } \\
\text { matematis }\end{array}$ & 2,27 & 2,17 \\
\hline
\end{tabular}

Berdasarkan Tabel 8, diperoleh informasi $t$-Benferroni $>t_{\text {tab }}$. Atau dengan kata lain, pembelajaran cooperative learning type STAD lebih efektif daripada pembelajaran cooperative learning type TPS ditinjau dari aspek ketercapaian standar kompetensi, kemampuan komunikasi matematika, dan berpikir matematis.

Hasil penelitian ini pun kemudian sejalan dengan kajian teori yang mengungkapkan bahwa pembelajaran cooperative learning type STAD lebih efektif daripada pembelajaran cooperative learning type TPS ditinjau dari ketiga aspek yang diukur tersebut. Hal ini disebabkan karena dalam kelas STAD, siswa bukan hanya terlibat dalam menemukan konsep dan diskusi kelas saja, melainkan juga selalu termotivasi dalam 
meningkatkan nilai agar kelompok mereka mendapatkan penghargaan yang baik.

Selanjutnya, jika mengaitkan hasil penelitian ini dengan kajian penelitian yang relevan, maka hasil ini pun sejalan. Hal ini terlihat dari lebih banyak penelitian relevan yang merujuk pada pembelajaran cooperative learning type STAD lebih efektif daripada pembelajaran cooperative learning type TPS ditinjau dari aspek ketercapaian standar kompetensi, kemampuan komunikasi matematika, dan berpikir matematis siswa.

Meskipun hasil penelitian ini sudah sejalan dengan kajian teori dan penelitian yang relevan tetapi seperti yang sudah dijelaskan sebelumnya bahwa terdapat beberapa keterbatasan yang menjadi kendala dalam pelaksanaan penelitian ini. Berdasarkan atas hal tersebut, maka ada beberapa hal yang disarankan, antara lain: Peneliti hanya membatasi pada delapan kali pertemuan untuk kemudian menilai aspek ketercapaian standar kompetensi, kemampuan komunikasi matematika, dan berpikir matematis. Padahal untuk bisa mengetahui seberapa baik ketiga aspek tersebut berkembang membutuhkan waktu yang relatif lama. Peneliti hanya mengambil materi bangun ruang sisi datar saja dalam penelitian ini sehingga generalisasi terkait dengan hasil penelitian menjadi terbatas.

\section{SIMPULAN DAN SARAN}

\section{Simpulan}

Pembelajaran cooperative learning (type STAD dan TPS) efektif dan pembelajaran cooperative learning type STAD lebih efektif daripada pembelajaran cooperative learning type TPS ditinjau dari ketercapaian standar kompetensi, kemampuan komunikasi matematis, dan metode matematika.

\section{Saran}

Berdasarkan hasil serta temuan penelitian, dan dengan memperhatikan keterbatasan penelitian, saran yang dapat disampaikan adalah sebagai berikut: (1) Disarankan kepada guru untuk menggunakan pembelajaran cooperative learning (Student Teams Achievement Divisions) dan pembelajaran cooperative learning type TPS (Think-Pair-Share) dalam pembelajaran matematika.

Disarankan kepada peneliti lain agar memperluas materi yang digunakan dalam penelitian, sehingga memungkinkan generalisasi yang lebih luas. (2) Disarankan kepada guru agar dalam menerapkan pembelajaran cooperative learning, dapat mempersiapkan bahan ajar, LKS, alat dan bahan serta rencana pembelajaran yang memberi kesempatan lebih luas kepada siswa untuk mengeksplorasi pengetahuannya secara mandiri. (3) Disarankan kepada guru agar dalam meningkatkan berpikir matematis siswa, diharapkan menggunakan permasalahan-permasalahan nyata (real problems) yang sering siswa saksikan dalam kehidupan seharihari. (4) Disarankan kepada guru dalam meningkatkan kemampuan komunikasi matematika, diharapkan menggunakan permasalaha-permasalahan yang mampu memancing mereka untuk mengutarakan alasan dan argumentasi mereka dalam menyelesaikan masalah tersebut. (5) Disarankan kepada guru agar dalam meningkatkan ketercapaian standar kompetensi matematika, diharapkan menggunakan alat peraga, LKS yang membantu siswa menemukan konsep, banyak memberikan latihan soal dan membimbing siswa dalam menyelesaikan permasalahan yang lebih kompleks atau sulit.

\section{DAFTAR PUSTAKA}

Arcavi, A. (2007). Mathematical thinking in japanese classrooms: Diambil tanggal 10 juli 2013, dari http://www.crme.kku.ac.th/APEC/PDF \%202007/ Abraham\%20Arcavi.pdf.

Arra., C.T., D’ Antonio., M.D., Jr., D’ Antonio. (2011). Students' preferences for cooperative learning instructional approaches: Considerations for college teachers. Journal of Reseach in Education, 21, 1, 114-126.

Arends, R. I., \& Kilcher, A. (2010). Teaching for student learning (Becoming an accomplished teacher). New York: Routledge Ratlor.

Bonomo, M.F.C. (2007). Mathematical thinking like angular stone in the understanding of real world phenomena: Diambil pada tanggal 1 agustus 2013, dari http://www.criced.tsukuba.ac.jp/math/ap ec/apec2007/progress_report/specialists_ session/Francisco_Cerda_Bonomo.pdf.

Borich, G. D. (2007). Effective teaching methods "research-based practice" $\left(6^{\text {th }}\right.$ $e d)$. Columbus: Pearson Education Inc.

Depdiknas. (2006) Peraturan Menteri Pendidikan Nasional RI nomor 22, 
tahun 2006, tentang standar isi. Jakarta: Depdiknas.

Depdiknas. (2006). Peraturan Menteri Pendidikan Nasional RI nomor 23, tahun 2006, tentang standar kompetensi lulusan. Jakarta: Depdiknas.

Depdiknas. (2007). Peraturan Menteri Pendidikan Nasional RI nomor 41, tahun 2007, tentang standar Proses. Jakarta: Depdiknas.

DIKTI. (2011). Defenisi dan pengertian kompetensi dan learning outcomes. Kemendikbud.

Hermawan, T. (2007). Pembelajaran berbasis masalah untuk meningkatkan kemampuan penalaran matematis siswa SMP. Cakrawala Pendidikan, 1, 41-62.

Kaddoura, Mahmoud. (2013). Think pair share: a teaching learning strategy to enhance students' critical thinking. West Monroe: Educational Research Quarterly.

Katagiri, S. (2007). Mathematical thinking and how to teach it: Tokyo: CRICED, University of Tsukuba.

Lee, C. (2006). Language for learning mathematics: assessment fotlLearning in practice. New York: Open University Press.

Mahmudi, A. (2009). Komunikasi dalam pembelajaran matematika. Journal MIPMIPA UNHALU volume 8, nomor 1 , Februari 2009. http://staff.uny.ac.id/sites/default/files/pe nelitian/Ali\%20Mahmudi,\%20S.Pd,\%20 MP.d,\%20Dr./Makalah\%2006\%20Jurnal \%UNHALU\%202008\%20_Komunikasi $\% 20 \mathrm{dlm} \% 20$ Pembelajaran\%20Matemati ka_.pdf. Diambil pada tanggal 21 Maret 2013.

Majoka., I.M., Dad., M.H., Mahmood., T. (2010). Student team achievement division (STAD) as an active learning strategy: Emperical evidence from mathematics classroom. Journal Educations and Sociology, 16-21.
Marsigit, Susanti, M., \& Arliani. (2007). Lesson study on mathematical thinking: developing mathematical methods in learning the total area of a right circular cylinder and sphere as well as the volume of a right circular cone of the indonesian 8th grade students. Diambil tanggal 8 september 2013, dari http://home.kku.ac.th/crme/APEC/PDF \%202007/Marsigit.pdf.

Maton, K., \& Moore, R. (2010). Social realism, knowledge and the sociology of education: coalitions of the mind. New York: Continuum.

Shininger, K. A. (2006), The benefits of using STAD in a middle school mathematics classroom. Diambil tanggal 12 Januari 2014, dari www. http://etd.ohiolink.edu/sendpdf.cgi/Shininger\%20Kar1\%20A.pdf?def 1281639234.

Slavin, R.E. (1995). Cooperative learning: teori, riset, and praktik $\left(2^{\text {th }} e d\right)$. Sydney: AllymandBroon.

Stacey, K. (2007), What is mathematical thinking and why is it important?. Progress report of the APEC project: "Colaborative Studies on Innovations for Teaching and Learning Mathematics in Diferent Cultures (II) - Lesson Study focusing on Mathematical Thinking -", Tokyo: CRICED, University of Tsukuba.

Steven, J. P. (2009). Applied multivariate statistics for the social sciences $\left(5^{\text {th }} \mathrm{ed}\right)$. New York: Routledge Taylor \& Francis Group.

Young, M. F. D. (1998). The Curriculum of the Future From the 'New Sociology of Education' to a Critical Theory of Learning. London: Falmer Press.

Zakaria, E., \& Iksan, Z. (2007). Promoting cooperative learning in science and mathematics education: a malaysian perpective. Selangor: Eurasia Journal of mathematics, 35-39. 